\title{
СОВРЕМЕННЫЕ КРИТЕРИИ РАЗВИТЫХ СЕЛЬСКОХОЗЯЙСТВЕННОЙ И ПИЩЕВОЙ ПРОМЫШЛЕННОСТИ В ЭПОХУ ИННОВАЦИОННЫХ РАЗРАБОТОК И ЦИФРОВЫХ РЕШЕНИЙ
}

\author{
(c) 2021 Ратнер Дмитрий \\ аспирант \\ Самарский государственный экономический университет, Россия, Самара \\ E-mail: ratner_9d@mail.ru
}

В статье рассматривается современное сельское хозяйство в эпоху цифровизации и внедрения инновационных разработок. Описано использование интернета вещей (IоT), облачных вычислений и больших данных, которые оказали огромное влияние на эффективность текущих процессов. Несколько фермерских хозяйств управляют фермами удаленно, используя сенсорные технологии, беспилотные летательные аппараты и другие устройства, которые собирают жизненно важные данные о свойствах почвы, воздухе, состоянии сельскохозяйственных культур и погодных условиях. Эти данные позволяют фермерам и агробизнесу внимательно следить за выращиванием сельскохозяйственных культур, оптимизировать использование агрохимикатов и природных ресурсов и быстро адаптироваться к меняющимся условиям окружающей среды. Предметом исследования является отрасль сельского хозяйства. Объектом исследования выступали инновационные технологии в сфере сельского хозяйства. Были рассмотрены работы ведущих специалистов в области сельского хозяйства: В. В. Годин, Южанинова Л., Дятлова А. Г.

Было показано, что существует множество экологических и социально-экономические аспектов, которые влияют на сельское хозяйство на разных этапах производственной цепочки. От управления скудными ресурсами по переработке отходов до новых решений для пестицидов и удобрений: многие темы, связанные с устойчивостью, играют огромную роль в сельском хозяйстве. В качестве примера оптимизации отрасли приведены самоходные зерноочистительные машины, которые в несколько раз рентабельнее по сравнению с использованием стационарных зерноочистительных комплексов.

Совсем недавно агрономы стали использовать зернометатели - это сельскохозяйственная машина, предназначенная для быстрой загрузки зерна, готового к транспортировке, формированию, опрокидыванию и переворачиванию штабелей зерна в элеваторах, зерновых складах и зерновых бункерах. Теперь очистить зерно от легких примесей можно также с помощью зернометателей. Использование зернометателей более выгоднее и эффективнее, чем применение шнековых аналогов. Недостатки зернопогрузчика шнекового типа заключаются в дроблении зерна при работе шнека. Использование зернометателей современного производства обеспечивает минимум дробления зерна, они самоходные, дальность полета зерна достигает 25 метров при движении до 170 тонн в час.

Ключевые слова: инновации, сельское хозяйство, Интернет Вещей, цифровизация, экология, устойчивое развитие, фермерские предприятия, оптимизация.

В развивающихся странах ИКТ в сельском хозяйстве предоставляют фермерам жизненно важную информацию, касающуюся посева, защиты растений и повышения плодородия почвы, что позволяет им повысить продуктивность сельского хозяйства. Рекомендации и предупреждения, связанные с погодой, помогают им подготовиться к спорадическим событиям, таким как наводнения, засуха или даже вспышки вредителей и болезней, предотвращая значительную потерю урожая. ИКТ также предостав- ляют им надежный канал для поиска лучшей рыночной цены на местных рынках и других ежедневных обновлений для своей продукции, чтобы гарантировать получение справедливой прибыли.

Тенденция растущего проникновения недорогой мобильной связи, телефонии и Интернета становится дополнительным преимуществом для фермеров, живущих в отдаленных районах нескольких развивающихся стран. Доступ к недорогим мобильным устройствам теперь упро- 
стил для них получение дополнительной информации и услуг, которые позволяют принимать обоснованные решения.

Теперь использование ИКТ гарантирует это с помощью нескольких кнопок, агрономы могут подключиться к глобальной сети фермеров, агрономов, предприятий и других поставщиков услуг, чтобы быть в курсе последних практик выращивания сельскохозяйственных культур [5].

Для политиков существует свое преимущество. Внедрение ИКТ в сельское хозяйство заключается в том, что обмен информацией позволяет им лучше понять ситуацию на местном уровне, что будет способствовать разработке и реализации политики аграрного и сельского развития, приносящей пользу фермерам. Широкий охват ИКТ даже в самых отдаленных местах также может помочь им в решении вопросов, касающихся гендерных предубеждений, расширения прав и возможностей женщин и других социально-экономических проблем [7].

Использование ИКТ существенно изменило сельское хозяйство и в развитых странах в другом масштабе. Интернет вещей (IoT), облачные вычисления и большие данные оказали огромное влияние на эффективность текущих процессов. Несколько фермерских хозяйств управляют фермами удаленно, используя сенсорные технологии, беспилотные летательные аппараты и другие устройства, которые собирают жизненно важные данные о свойствах почвы, воздухе, состоянии сельскохозяйственных культур и погодных условиях [10]. Эти данные позволяют фермерам и агробизнесу внимательно следить за выращиванием сельскохозяйственных культур, оптимизировать использование агрохимикатов и природных ресурсов и быстро адаптироваться к меняющимся условиям окружающей среды. Использование ИКТ и инструментов точного земледелия привело к повышению эффективности и снижению затрат. Оно также предоставляет инструменты для принятия решений, которые повышают продуктивность сельского хозяйства, а также помогают эффективно управлять природными ресурсами.

Некоторые из интернета вещей, в частности, имеют несколько применений в сельском хозяйстве, от мониторинга почвы в реальном времени до здорового роста растений и животных с использованием датчиков на определенных местах для отслеживания происхождения продукта или сельскохозяйственного товара и его воздей- ствия на окружающую среду, а также среду его хранения в цепочке поставок [4].

Ученые полагают, что к 2030 году в сельском хозяйстве появится искусственный интеллект, где датчики и машины, основанные на встроенном искусственном интеллекте и возможностях анализа данных, будут способны самооптимизироваться и инициировать действия самостоятельно, без особого вмешательства человека [11].

Благодаря новейшим инновационным технологиям сельскохозяйственные машины, метеостанции и полевое оборудование становятся «умнее». Новые решения могут управлять собой, принимать решения, обеспечивать обзор в реальном времени и комплексный анализ. Их объединяет цель сократить количество повседневных операций, которые делают жизнь фермеров слишком занятой.

Агроном Аджеррис разработал полевых роботов, которые могут перемещаться по саду и предоставлять конкретную информацию о своих областях деятельности, став консультантами, опрыскивателями, картографами и специалистами по оценке урожайности для производителя. «Tracdrone» может заменить рабочую силу во всех этих трудоемких повседневных делах с помощью беспилотного трактора с дистанционным управлением. Чтобы обеспечить поддержку при сборе урожая и опылении, «Roboticsplus» разработала беспилотный наземный транспорт, который может помочь фермерам в основные этапы сезона фруктов [2].

Устойчивое развитие - одна из мегатенденций, формирующих нашу жизнь. То же самое и с сельским хозяйством: сектор по своей природе соответствует этому подходу, и на рынке появляется множество решений, которые пытаются сделать выращивание фруктов более экологичным и устойчивым [8].

Существует множество экологических и социально-экономические аспектов, которые влияют на сельское хозяйство на разных этапах производственной цепочки. От управления скудными ресурсами по переработке отходов до новых решений для пестицидов и удобрений: многие темы, связанные с устойчивостью, играют огромную роль в сельском хозяйстве.

Вода - один из важнейших ресурсов для сельского хозяйства, она имеет решающее значение для производителей. Таким образом, получение дополнительной информации и инструменты управления водой могут быть стратегическими 
элементами для хорошего процесса выращивания [6].

Не так давно современные агрономы стали использовать самоходные зерноочистительные машины. Они - в несколько раз рентабельнее по сравнению с использованием стационарных зерноочистительных комплексов, потому что:

- упрощается вся процедура обработки урожая, так как отсутствует необходимость проектировать и строить стационарные комплексы, строить подъездные пути к ним, обслуживать дополнительные транспортные средства, погрузочную технику и персонал;

- при использовании самоходных зерноочистительных машин уборка осуществляется непосредственно на складе зерна, в связи с чем отпадает необходимость в транспортировке зерна туда и обратно на склад, а значит, сокращаются затраты на погрузку, транспортировку и разгрузку;

- самоходные зерноочистительные машины самостоятельно перемещаются по складу и загружают себя нечистым зерном без помощи другой техники или людей;

- самоходные зерноочистительные машины могут загружать зерно в грузовик или прицеп без помощи зернометателей, погрузчиков, элеваторы и другое оборудование;

Мощность таких самоходных зерноочистительных и сортировочных машин высока; она достигает 25 тонн в час, что позволяет быстро очистить большое количество зерна.

Самоходные зерноочистительные машины используются для очистки от примесей початков, злаков, зернобобовых культур, сорго, подсолнечника, кукурузы, льна и масличного рапса. Их можно использовать как в помещении, так и на открытом воздухе зерновых бункеров. Они обеспечивают качественную очистку за счет использования сеток, щеток и регулируемого воздушного потока.

Дополнительным преимуществом зерноочистительных машин является возможность сушить зерно одновременно с его очисткой. Использование самоходной зерноочистительной и сортировочной машины будет особенно удобно для фермерских предприятий, имеющих зернохранилища или сельскохозяйственных кооперативов.

Совсем недавно агрономы стали использовать зернометатели - это сельскохозяйственная машина, предназначенная для быстрой загруз- ки зерна, готового к транспортировке, формированию, опрокидыванию и переворачиванию штабелей зерна в элеваторах, зерновых складах и зерновых бункерах. Теперь очистить зерно от легких примесей можно также с помощью зернометателей.

Использование зернометателей более выгоднее и эффективнее, чем применение шнековых аналогов. Недостатки зернопогрузчика шнекового типа заключаются в дроблении зерна при работе шнека. Использование зернометателей современного производства обеспечивает минимум дробления зерна, они самоходные, дальность полета зерна достигает 25 метров при движении до 170 тонн в час [1].

Зернометатели имеют весомое отличие от вакуумных зернопогрузчиков, поскольку потребляют меньше электроэнергии при более высокой производительности. Благодаря способности быстро перемещаться, мобильные зерноочистительные машины просто незаменимы для послеуборочной обработки. Это лучший выбор для сельскохозяйственных кооперативов, крупных хозяйств или компании, специализирующиеся на предоставлении услуг по очистке зерна и подготовке семян.

С помощью этого оборудования можно разделить зерно как по удельному весу за счет использования мощный воздушный поток, так и по размеру сит с разными ячейками.

«Вакуумно-сетчатый очиститель ОВС-50»мобильный гибрид зерноочистительной машины и шнекового зернопогрузчика, демонстрирующий высокую производительность. Он осуществляет очистку зернового материала от мелких примесей на ситах и легкие примеси с помощью системы аспирации. Его даже можно буксировать на автомобиле. Более эффективное решение для сортировки, способное одновременно разделять до трех продуктов, - это мобильные зерновые ОВС-354MD и ОВС-355M очистные комплексы. Мобильные и гибкие в выборе сортируемых культур, эти машины могут оснащаться дезинфицирующим средством для семян и системой взвешивания [3].

Для достижения высококачественной очистки зерна в этих комплексах используется роторная зерноочистительная машина ОВС-354 или OBC-355, оснащенная мощной аспирационной системой, а затем вращающимся цилиндром, содержащим от 3 до 5 последовательно расположенных сит. Оператор может отклонить поток, 
проходящий через любое сито в желаемом направлении. Это необходимо для настройки желаемого режима работы и обработки зерна.

В зависимости от потребностей оператор сможет изменить схему использования: простая, быстрая очистка, калибровка, высокоточная калибровка, разделение семян нескольких культур между собой и от примесей, протравливание семян. Мобильные комплексы OBC-354MD и OBC-355M смонтированы на трейлер - автомобиль, который можно быстро переместить. Для перехода из транспортного режима в рабочий режим требуется всего 10 минут.

Таким образом, инновации никогда не были так важны, как сейчас, когда фермеры и сельское хозяйство сталкиваются с потребностями общества и цифровизацией всех сфер жизнедеятельности [9]. Инновации должны обеспечивать правильный баланс между производительностью и устойчивостью в сельском хозяйстве, помогая фермерам не только производить больше, но и повышать их урожайность.

Так, интернет вещей (IoT), облачные вы- числения и большие данные оказали огромное влияние на эффективность текущих процессов. Несколько фермерских хозяйств управляют фермами удаленно, используя сенсорные технологии, беспилотные летательные аппараты и другие устройства, которые собирают жизненно важные данные о свойствах почвы, воздухе, состоянии сельскохозяйственных культур и погодных условиях.

Эти данные позволяют фермерам и агробизнесу внимательно следить за выращиванием сельскохозяйственных культур, оптимизировать использование агрохимикатов и природных ресурсов и быстро адаптироваться к меняющимся условиям окружающей среды. Но для перманентного улучшения отрасли необходимо учитывать социальные, экономические и политические контексты инноваций, которые должны быть изучены с помощью моделей и методов современного структурного анализа. Все это дает основу для дальнейшего использования большого количества исследовательских материалов.

\section{Библиографический список}

1. All About Grains: 21 Types of Grains [Электронный ресypc].URL: https://www.masterclass.com/articles/allabout-grains-21-types-of-grains (дата обращения: 28.09.2021).

2. Donovan A. 15 Medical Robots That Are Changing the World [Электронный pecypc].URL: https:// interestingengineering.com/15-medical-robots-that-are-changing-the-world (дата обращения: 28.09.2021).

3. MOBILE GRAIN CLEANER VACUUM WITH SIEVES OBC-50 [Электронный ресурс].URL: https://bim-agritech. com/en/mobile-grain-cleaner-vacuum-sieves-ovs-50 (дата обращения: 28.09.2021).

4. Блохина С.Ю. Интеллектуальное земледелие на основе интернета вещей / С. Ю.Блохина, Ю.И.Блохин // Земледелие. -2020 . - № 7. - С. 8-15.

5. Годин В. В. Сельское хозяйство в цифровую эпоху: вызовы и решения / В.В. Годин, М. Н. Белоусова, В. А. Белоусов, А.Е. Терехова // Электронный менеджмент в отраслях. - 2020. - № 1 (3). - С.4-16.

6. Дятлова А.Г. Инструменты управления рациональным природопользованием / А.Г.Дятлова, М.М. Милославская // Вестник экономической безопасности. - 2018. - № 4. - С. 205-213.

7. Использование технологий для изменения жизни [Электронный ресурc].URL: http://www.fao.org/faostories/article/ru/c/1105851/ (дата обращения: 28.09.2021).

8. Ланьшина T. А. Устойчивое развитие и цифровизация: необычный кризис COVID19 требует оригинальных решений / Т. А. Ланьшина, В. А. Баринова, А.Д. Кондратьев, М. В. Романцов // Вестник международных организаций. - 2020. - № 4 (15). DOI: 10.17323/1996-7845-2020-04-05.

9. Сураева М.О. Основные возможности для развития инновационного предпринимательства / М. О.Сураева, Р.И. Хансевяров // ФУНДАМЕНТАЛЬНАЯ НАУКА И ТЕХНОЛОГИИ - ПЕРСПЕКТИВНЫЕ РАЗРАБОТКИ. 2019. - С. 73-76.

10. Эльдиева Т. М. Направления использования умных инноваций в сельском хозяйстве / Т. М. Эльдиева // Международный сельскохозяйственный журнал. - 2018. - № 6 (366). - С. 47-51.

11. Южанинова Л. 15 технологий, которые изменят сельское хозяйство [Электронный pecypc].URL: https:// news.rambler.ru/other/42951479-15-tehnologiy-kotorye-izmenyat-selskoe-hozyaystvo/ (дата обращения: 28.09.2021). 